\title{
Analisa Diplomasi Budaya Indonesia Melalui Tari Saman Gayo Dalam Mengukuhkan Identitas Nasional Bangsa
}

\section{Hardi Alunaza SD}

Staf Direktorat Penelitian dan Pengabdian Masyarakat, Universitas Muhammadiyah Malang Kampus Telogo Mas, Malang 65144

Email: hardialunaza@gmail.com

Diterima pada 16 November 2014, Disetujui pada 31 Januari 2015

\begin{abstract}
Diversity of Indonesian culture must be maintained by preserving and protecting from the claim of another country. This paper is aim to explain how the existence of traditional culture is very important. In fact, it has big role in shaping the national identity. The writer using national identity concept to analyze this phenomena. Indonesia is doing diplomacy by proposing Saman Gayo Dance as intangible cultural heritage original from Indonesia to UNESCO. This is done in order to preserve Saman dance from extinction and functioned as affirmation of the national identity of Indonesia.

Keywords: Cultural Diplomacy, Saman Gayo Dance, National Identity
\end{abstract}

\begin{abstract}
Abstrak
Keanekaragaman budaya Indonesia harus dipertahankan dengan melestarikan dan memproteksi dari klaim negara lain. Tulisan ini bertujuan untuk menjelaskan bagaimana kebudayaan daerah menjadi penting bagi Indonesia. Pada kenyataannya, budaya memberi andil yang sangat besar bagi pembentukan jati diri bangsa. Penulis menggunakan konsep identitas nasional untuk menganalisa fenomena ini. Indonesia melakukan diplomasi dengan mengajukan Tari Saman Gayo menjadi warisan budaya tak benda asli Indonesia ke UNESCO. Hal tersebut dilakukan guna menjaga Tari Saman agar tidak punah sekaligus sebagai suatu proses pengukuhan identitas nasional Bangsa Indonesia.

Kata kunci: Diplomasi Budaya, Tari Saman, Identitas Nasional
\end{abstract}

\section{PENDAHULUAN}

Pada rentang waktu 2007-2012, Malaysia sudah mengklaim tujuh budaya milik Indonesia dan mengakui itu sebagai warisan budaya mereka. Klaim budaya pertama yang dilakukan Malaysia terhadap budaya asli Indonesia adalah pada November 2007 terhadap kesenian Reog Ponorogo. Selanjutnya, klaim itu berlanjut pada Desember 2008 yaitu lagu Rasa Sayange dari Kepulauan Maluku (antaranews.com: 2007). Berikutnya adalah budaya batik, kemudian Tari Pendet juga diklaim oleh salah satu iklan pihak swasta yang muncul pada promo pariwisata di televisi pada program Discovery Channel berjudul enigmatic Malaysia pada Agustus 2009. Selanjutnya instrumen dan ansambel musik angklung pada Maret 2010 dan tari tor-tor dan Gondang Sambilan yang merupakan kesenian asli dari Sumatera Utara.

Dengan berbagai kebudayaan yang berbeda dan unik tidak menutup kemungkinan hal tersebut menjadi terganggu akibat munculnya globalisasi. Globalisasi dan westernisasi yang melanda kawasan Asia Tenggara khususnya Indonesia, menjadikan masyarakatnya tidak peduli dan kurang melestarikan budayanya sehingga budaya tersebut menjadi terabaikan. Inilah yang menjadi peluang bagi negara 
tetangga untuk merebutnya, karena saat ini bukan hanya wilayah fisik yang mengandung nilai komersial tinggi tetapi juga kekayaan budaya. Contohnya warisan batik, pentas galigo, angklung bambu, kolintang, kesenian Dayak dan masih banyak lagi warisan budaya yang terganggu kepemilikannya (Riski Adi, 2011: 1)

Keanekaragaman budaya yang dimiliki oleh negara ini tentunya mempunyai banyak sisi positif, salah satunya Indonesia bisa dikenal dalam pergaulan dunia internasional melalui budayanya yang sangat kaya dan beragam. Budaya ini bisa digunakan sebagai daya tarik atau pemikat untuk mendatangkan wisatawan asing ke Indonesia. Namun, kurangnya perhatian terhadap pelestarian budaya daerah, baik dari pemerintah maupun dari masyarakat mengakibatkan budayabudaya tersebut terancam hilang dari kedaulatan Indonesia di tengah maraknya arus globalisasi. Sejak banyaknya klaim budaya yang dilakukan oleh Malaysia, Indonesia menjadi semakin terlihat hati-hati dalam menjaga kelestarian budayanya.

Tantangan semangat kebangsaan lahir dengan semakin majunya kehidupan manusia, dimana jarak tidak lagi menjadi suatu halangan. Globalisasi telah menjadi tombak dan mengikis semangat cinta tanah air. Globalisasi telah menimbulkan masalah bagi eksistensi negara dan bangsa. Globalisasi menjadi ancaman disintegrasi (Hendrastomo, 2007). Secara perlahan globalisasi juga menjadi penyebab pengikis identitas nasional bangsa (Perwita, 2011: 136).

Masyarakat Indonesia khususnya anak muda banyak yang lupa akan identitas diri mereka sebagai bangsa Indonesia karena maraknya globalisasi. Salah satu realitanya adalah anak muda Indonesia lebih tertarik terhadap produk budaya luar. Hal itu secara jelas mengikis rasa nasionalisme generasi muda. Globalisasi membuat banyak orang memiliki loyalitas sehingga menambah dan mungkin akan dapat mengesampingkan perasaan dari solidaritas nasional yang sebelumnya telah diberikan secara sah (Rudy, 2003: 40).

Budaya daerah merupakan kekayaan bangsa yang perlu diperhatikan dan ditangani secara serius. Keberadaan budaya daerah, menjadi penting karena budaya dalam kenyataannya memberi andil yang sangat besar bagi pembentukan jati diri bangsa, dan juga bagi proses regenerasi bangsa. Untuk itu, Indonesia harus memperhitungkan seluruh aspek keberagaman upaya pembangunan bangsa sesuai dengan kondisi perkembangan zaman. Lebih jauh, keberadaan budaya Indonesia harus diperhatikan secara serius karena hal tersebut mampu memberikan makna tersendiri bagi citra bangsa Indonesia di mata dunia (Manuaba, 1999).

Semua pihak ikut harus berperan serta dalam mempertahankan budaya dan seluruh hak cipta yang ada di Indonesia, baik oleh pemerintah, masyarakat, maupun perusahaan-perusahaan swasta, serta lembagalembaga non-pemerintah. Dalam hal hak cipta budaya, seni dan lainnya, dapat dilakukan dengan cara pemerintah dapat melakukan permudahan regulasi hak cipta seni perorangan maupun lembaga, dan mempercepat penetapan hak cipta berbagai budaya Indonesia yang hanya bisa dilakukan dan dimiliki pemerintah.

Tulisan ini terbagi menjadi tiga poin penting dalam menjelaskan dan menganalisa Tari Saman Gayo sebagai diplomasi budaya Indonesia ke UNESCO guna pengukuhan identitas nasional bangsa. Pertama, proses diplomasi Indonesia untuk memperoleh pengakuan Tari Saman Gayo dari UNESCO, kedua adalah analisa Tari Saman sebagai soft power dalam diplomasi Indonesia. Serta, praktek dan hambatan Indonesia dalam melakukan diplomasi Tari Saman.

\section{METODOLOGI}

\section{KONSEP IDENTITAS NASIONAL}

Identitas nasional dalam konteks bangsa Indonesia memiliki penjelasan berupa nilai-nilai budaya yang tumbuh dan berkembang dalam berbagai kehidupan yang merupakan bagian dari kesatuan Indonesia yang menjadi kebudayaan nasional dengan acuan Pancasila dan Bhineka Tunggal Ika sebagai dasar dari proses perkembangannya. Sehingga dapat dikatakan bahwa identitas nasional bangsa Indonesia Pancasila yang aktualisasinya terlihat dalam penataan nilai-nilai budaya yang tercermin dalam identitas nasional dan 
senantiasa berkembang demi kemajuan (Busrizalti, 2013: 19).

Identitas nasional Indonesia merujuk kepada bangsa yang majemuk yang tergambar dari kemajemukan suku bangsa, agama, kebudayaan, serta bahasa. Kebudayaan merupakan salah satu unsur identitas nasional yang merupakan patokan nilai-nilai etika dan moral baik yang tergolong ideal atau yang seharusnya maupun yang bersifat operasional dan aktual dalam kehidupan sehari-hari. Seperti banyaknya budaya yang ada di Indonesia yang membentuk identitas nasional sebagai bangsa yang kaya akan kemajemukan.

Menurut Koento Wibosono (2008: 41) bahwa identitas nasional merupakan menifestasi nilai-nilai budaya yang tumbuh dan berkembang dalam aspek kehidupan suatu bangsa dengan ciri khas yang berbeda dengan bangsa lain. Identitas nasional merupakan identitas yang melekat dalam suatu kelompok yang didasarkan pada adanya kesamaan budaya, agama, bahasa, keinginan, dan cita-cita. Terkait penelitian ini, penulis melihat bahwa identitas nasional suatu bangsa tercermin dari nilai-nilai budaya yang dimiliki oleh suatu negara. Dimensi budaya merupakan salah satu elemen dalam pembentukan identitas nasional. Identitas nasional bangsa Indonesia dalam hal ini tercermin dari dimensi budaya yang dimiliki oleh Indonesia yakni Tari Saman Gayo.

Tulisan ini merupakan penelitian deskriptif dengan pendekatan kualitatif, dimana penulis berusaha untuk memberikan gambaran atau mendeskripsikan keadaan objek serta permasalahan yang ada. Oleh karena itu, metode deskriptif di sini diharapkan dapat mencapai tujuan penelitian, yaitu menggambarkan secara jelas fakta dan karakteristik objek yang diteliti secara tepat.

\section{HASIL DAN PEMBAHASAN}

PENGAKUAN UNESCO ATAS TARI SAMAN GAYO

Sesuai Konvensi 2003 UNESCO, dalam Pasal 2, Ayat 1 disebutkan bahwa warisan budaya tak benda meliputi segala praktek, representasi, ekspresi, pengetahuan, keterampilan serta alat-alat, benda, artefak dan ruang-ruang budaya terkait dengannya yang diakui oleh berbagai komunitas, kelompok, dan dalam hal tertentu perseorangan sebagai bagian warisan budaya mereka. Warisan Budaya Tak benda dikenal lebih akrab sebagai warisan budaya hidup.

Bandingannya adalah situs alam dan situs budaya, yang dikenal sebagai warisan benda.

UNESCO telah mengadopsi Konvensi tentang Pelindungan Warisan Budaya Tak benda pada Sesi ke32 Konferensi Umum yang dilaksanakan di Paris, pada 17 Oktober 2003. Konvensi 2003 mulai beroperasi sejak April 2006 yang bertujuan meningkatkan visibilitas atau kesadaran umum, mendorong penghormatan dan pelindungan beraneka ragam warisan budaya tak benda atau budaya hidup melalui kerja sama antara pemerintah dan komunitas pada tingkat nasional, sub regional, regional maupun internasional.

Konsep UNESCO dalam warisan budaya secara luas menerapkan definisi antropologi budaya, yang telah memainkan peran sentral dalam membuat orang sadar akan pentingnya warisan budaya masyarakat non Barat yang sampai pada dewasa ini kurang dihargai. Pada inti dari konsep ini, yang menyokong misi UNESCO adalah pemahaman bahwa esensi dari budaya tidak begitu banyak produk sebagai kegiatan budaya dan ekspresi simbolik yang dianut oleh orangorang. Selain itu, konsep budaya UNESCO membuat penjelasan bahwa warisan budaya tak benda dimiliki bukan hanya oleh negara tetapi oleh individu-individu, kelompok, dan masyarakat terkait dengan asal-usul dan penggunaan (www.unesco.org, 2014).

Indonesia mengajukan Tari Saman Gayo ke UNESCO sebagai salah satu warisan budaya dunia tak benda sejak Maret 2010 yang disertai dengan proposal kertas akademis. Tari Saman Gayo telah memenuhi empat kriteria yang ditetapkan oleh UNESCO. Empat kriteria tersebut meliputi keaslian atau originalitas, keunikan, filosofi yang bersifat universal, serta memiliki daya tular terhadap kehidupan masyarakat Indonesia secara meluas (BBC, 2011).

Arif Rachman (www.unesco.org, 2014) menyebutkan:

"Yang pertama originilitas, yang kedua keunikan dan 
yang ketiga apakah dia mempunyai nilai-nilai filosofi yang universal atau tidak, dan yang keempat apakah dia mempunyai daya tular ke masyarakat Indonesia secara meluas. Lalu yang kedua UNESCO juga harus memastikan bahwa program-program yang diajukan itu mempunyai program proteksi atau pelestarian dan mempunyai program promosi, program yang sifatnya edukasi yang bisa ditangkap oleh generasi muda yang lainlainnya."

Terkait kriteria yang ditetapkan UNESCO, Indonesia telah memenuhi untuk keempat kriteria tersebut:

U.1 Elemen merupakan warisan budaya dunia yang bersifat asli dan diwariskan dari generasi ke generasi, memiliki filosofi sebagai penyambung kekerabatan, diciptakan oleh masyarakat dan kelompok untuk menunjukkan identitas komunitas. Di dalamnya terdapat nilai-nilai ketuhanan, patriotisme, kekuatan, dan sejarah masyarakat Gayo Lues yang berkelanjutan.

U.2 Unsur ini membutuhkan perlindungan yang mendesak. Karena memiliki risiko terhadap kelangsungan hidup, meskipun sudah ada upaya dari masyarakat, kelompok, individu, atau negara yang bersangkutan. Dalam hal ini, negara-negara harus bisa memperlihatkan dan menjelaskan secara spesifik bahwa unsur yang didaftarkan benar-benar membutuhkan perlindungan dan unsur yang didaftarkan juga mempunyai kriteria yang unik.

U.3 Langkah-langkah perlindungan yang diuraikan dapat memungkinkan masyarakat, kelompok, atau individu yang bersangkutan untuk melanjutkan praktek dan transmisi unsur. Negara yang bersangkutan harus bisa menguraikan strategi pengamanan yang koheren dan sistematis. Dengan anggaran dan jadwal yang sesuai. Langkah-langkah ini juga harus bisa meningkatkan kapasitas dan memberikan pengetahuan terhadap masyarakat.

U.4 Unsur yang dinominasikan diikuti partisipasi seluas mungkin masyarakat, kelompok, komunitas, atau individu yang bersangkutan dan dengan persetujuan bebas mereka, didahulukan dan dinformasikan. Partisipasi dan keikutsertaan masyarakat merupakan bagian dasar bagi semua kriteria. Terutama dalam perencanaan dan pelaksanaan langkah-langkah yang disusun (UNESCO, 2011).

Tari Saman Gayo yang berasal dari Daerah Gayo Lues Aceh itu disahkan sebagai warisan budaya dunia dalam sidang UNESCO pada 24 November 2011 di Bali International Convention Center. Berkas nominasi Tari Saman disusun secara teliti dan diajukan kepada UNESCO pada bulan Maret 2010 oleh pihak Pemerintah Indonesia. Pengajuan berkas tersebut setelah mendapatkan dukungan penuh dari Pemerintah Pusat, Pemerintah Provinsi Aceh, Bupati Gayo Lues, dan masyarakat Gayo. Setelah berkas diperiksa oleh Sekretaris UNESCO dan Pakar Internasional untuk selanjutnya diajukan dalam sidang di Bali.

\section{SOFT POWER DALAM DIPLOMASI TARI SAMAN GAYO}

Bentuk soft power Indonesia adalah dengan menekankan pada penguasaan terhadap bentuk-bentuk kekuatan nasional negara yang tidak terlihat seperti ideologi, kebudayaan, dan nilai-nilai moral (intangible resources). Soft power merupakan kemampuan untuk menarik dan mempengaruhi aktor lain untuk mendapatkan apa yang kita inginkan tidak melalui pemaksaan yang bersifat kekerasan. Kemampuan itu sendiri diwujudkan oleh Indonesia dengan tiga cara yaitu menarik, memikat, dan menjadikan milik, di mana dalam hal ini adalah dengan menggunakan Tari Saman sebagai soft power yang diaktualisasikan sebagai kekuatan nasional Indonesia yang didasarkan pada nilai-nilai, ideologi dan ciri-ciri budaya yang secara konkret dengan mendapatkan pengakuan dari UNESCO. Sehingga dengan pengakuan tersebut, Indonesia terlihat mampu menjaga dan melindungi kekayaan budayanya dari gangguan budaya lain.

Mendapatkan pengakuan akan Tari Saman Gayo sebagai warisan budaya tak benda dari UNESCO untuk mengukuhkan identitas nasional bangsa merupakan bentuk soft power Republik Indonesia dalam mendekati bangsa lain, karena pentingnya menjaga dan melindungi budaya-budaya Indonesia yang memiliki banyak sekali keragaman budaya (UNESCO, 2009). Pemerintah Indonesia juga 
menginginkan agar Tari Saman dapat dibawa menuju masyarakat dunia secara meluas dan dapat dijadikan sebagai salah satu kekuatan dalam menunjukkan identitas nasional akan bangsa yang memiliki keanekaragaman budaya. Seperti yang disampaikan Menteri Koordinator Bidang Kesejahteraan Rakyat (Laksono, 2011: 2), dalam pidatonya pada pembukaan sidang komite ke-6 untuk Intangible Cultural Heritage under UNESCO:

"Indonesia and some of countries in the world are very rich with cultural heritage, both of tangible and intangible. We relize that cultural heritage is valuable and informative for human being particulary in studying their cultural diversity of the past. We are very pride with our cultural heritage. It can be used to strengthen national identity. Moreover, every country are very pride if they have the World Intangible Cultural Heritage under UNESCO. Therefore the World Intangible Cultural Heritage must be safeguarded and developed in order to make them in good condition and can be utilized by next young generation.."

Pidato tersebut menunjukkan bahwa diakuinya Tari Saman yang merupakan warisan budaya Indonesia mampu menjadi sebuah kekuatan identitas bagi Bangsa Indonesia. Di samping untuk tetap menjaga budaya agar tidak punah, hal tersebut juga berguna untuk memperkuat identitas bangsa bahwa Tari Saman merupakan budaya asli Indonesia sehingga diharapkan mampu menjadi sebuah soft power bagi Indonesia.

Hal itu sejalan dengan konsep yang menjelaskan bahwa budaya sebagai identitas suatu bangsa adalah wujud soft power yang dimiliki oleh negara (Wibawarta, 2012: 12). Maka, melestarikan Tari Saman dan budaya lainnya merupakan hal yang penting bagi Indonesia untuk menunjukkan identitas nasional bangsa terhadap negara lain dalam percaturan dunia internasional.

Pemerintah Indonesia ingin Tari Saman bisa dilihat di dunia internasional, dan menimbulkan citra positif terhadap budaya-budaya Indonesia. Dengan diakuinya Tari Saman oleh UNESCO, secara jelas menunjukkan kepada dunia internasional bahwa Tari Saman Gayo adalah warisan budaya asli Indonesia. Sehingga, elemen tersebut dapat digunakan oleh Indonesia dalam menunjukkan identitas nasionalnya baik di lingkungan domestik maupun di lingkup internasional.

Munculnya globalisasi dapat menimbulkan konflikkonflik, bentuk ketidakpedulian, serta masalahmasalah lainnya. Sehingga pemerintah Indonesia menginginkan dapat mengatasi kesenjangan tersebut agar tidak meluas melalui Tari Saman. Karena Tari Saman mempunyai nilai-nilai agama di dalam nyanyiannya, dan mempunyai arti kedamaian dalam setiap syairnya (Salam, 2014). Maka pemerintah Indonesia melihat adanya potensi Tari Saman yang dapat memperoleh hubungan dengan negara lain lebih baik.

Pengembangan soft power juga cocok bagi politik bebas aktif yang Indonesia anut karena di sinilah letak kekuatan diplomasi Republik Indonesia di masyarakat internasional yang lebih banyak ditentukan oleh berbagai prestasi, pesona, persuasi maupun keanekaragaman budaya yang dimiliki dibandingkan dengan faktor-faktor kekuatan militer. Bahwa diplomasi yang dilakukan Indonesia adalah untuk mengejar eksistensi negara di hadapan dunia melalui dimensi budaya yang merupakan keinginan hidup untuk terus mempertahankan kekayaan budaya yang dimiliki Indonesia untuk tantangan perkembangan dan eksistensi identitas nasional bangsa.

Soft power juga bisa digunakan sebagai sarana politik luar negeri oleh suatu bangsa. Dalam tulisan ini soft power yang dimaksud adalah dengan diplomasi Tari Saman Gayo yang merupakan seni, cara atau strategi dalam menyampaikan kebijakan kepada wakil-wakil negara lain demi memperjuangkan suatu kepentingan yaitu proses pengukuhan identitas nasional Indonesia. Soft power sebagai instrumen politik luar negeri juga mengalami perkembangan dari bentuk yang tradisional dengan menggunakan ancaman menjadi diplomasi yang lebih modern dengan pendekatan yang lebih lembut dan bersifat persuasif yakni dengan menggunakan soft power (Ayu Riska, 2012: 22).

Ada tiga sumber utama dalam soft power sebagai sarana politik luar negeri yakni, daya tarik budayanya, 
nilai politik dan kebijakan luar negerinya. Budaya adalah seperangkat nilai dan bentuk praktek dalam menciptakan makna terhadap suatu masyarakat yang mana bentuk budaya itu sendiri dapat berupa seni artistik, pendidikan, bahasa kesusastraan, hingga budaya dalam bentuk hiburan untuk masyarakat umum (musik, tarian, film). Kebudayaan suatu bangsa mengandung nilai-nilai yang universal dan kebijakan mempromosikan nilai-nilainya yang memiliki daya tarik bagi pihak lain dapat meningkatkan popularitas suatu negara karena daya tarik yang dibentuk melalui budaya tersebut (Joseph Nye. 2004: 5).

Tari Saman Gayo yang menjadi kepentingan penunjukan identitas bangsa karena kepentingan ini lebih kepada perlindungan suatu budaya yang terancam punah, yang pada dasarnya budaya Indonesia ini sangat berarti bagi masyarakat Indonesia, untuk dilestarikan dan menjadi suatu warisan budaya pada generasi-generasi muda agar tidak punah. Sehingga kepentingan ini berarti bahwa dengan adanya diplomasi budaya Indonesia melalui Tari Saman Gayo, diharapkan adanya kesadaran generasi muda dan warga Indonesia termasuk pemerintah untuk mempertahankan, menjaga, dan melestarikan budaya bangsa.

Bentuk kebijakan Indonesia dalam melakukan diplomasi dengan menggunakan elemen budaya tercermin dari cara yang ditunjukkan Kementrian Luar Negeri Republik Indonesia dalam berdiplomasi untuk mendapatkan pengakuan UNESCO atas Tari Saman Gayo sebagai warisan budaya dunia tak benda. Setelah mendapatkan pengakuan dari UNESCO, Indonesia juga tetap memperjuangkan melalui berbagai cara untuk mempertahankan eksistensi Tari Saman Gayo. Mulai dari pengadaan Saman Summit pada tahun 2012, kemudian pembentukan komunitas dan penampilan Tari Saman di luar negeri, hingga adanya kebijakan untuk memasukkan Tari Saman Gayo dalam kurikulum pendidikan. Semua langkah itu dilakukan Indonesia untuk menjaga eksistensi dan pelestarian Tari Saman.

Menurut analisis peneliti, dalam memperoleh pengakuan dari UNESCO, Indonesia melakukan strategi yaitu dengan melakukan diplomasi total. Di mana diplomasi tersebut tidak hanya melibatkan Pemerintah Indonesia saja secara umum, tetapi juga melibatkan seluruh komponen masyarakat Indonesia yang tergabung dalam satu sinergi untuk memperjuangkan Tari Saman sebagai suatu identitas bangsa Indonesia yang tercermin melalui dimensi budaya.

Arti diplomasi total yang penulis sebutkan bahwa Pemerintah Indonesia sebagai ujung tombak yang memperjuangkan keterlibatan seluruh stakeholder dalam diplomasi Tari Saman. Hal itu tercermin dari perjuangan para komunitas Tari Saman yang ada di Gayo Lues, mereka menyampaikan kepada Pemerintah Gayo Lues, kemudian Pemerintah Daerah tersebut, Pemerintah Indonesia melalui Kementrian Luar Negeri melakukan pengajuan proposal kepada UNESCO hingga Tari Saman masuk sebagai nominasi salah satu budaya yang membutuhkan pengakuan dan perlindungan dari pihak UNESCO.

Keberhasilan diplomasi Tari Saman bukan hanya tergantung upaya pemerintah tetapi juga semua masyarakat Republik Indonesia. Hal itu juga sesuai dengan kriteria warisan budaya tak benda dari UNESCO, di mana pada kriteria keempat disebutkan bahwa keterlibatan masyarakat, komunitas, atau individu sangat berpengaruh dalam memenuhi kriteria yang telah disebutkan.

Upaya menjadikan Tari Saman sebagai warisan budaya tak benda milik Indonesia, dibutuhkan adanya kerja sama, dukungan, serta komitmen dari semua elemen yang terlibat, di mana dalam penelitian ini yang diutamakan adalah adanya komitmen masyarakat Gayo Lues, komunitas Tari Saman, dan Pemerintah Indonesia. Sebagaimana disebutkan dalam bab sebelumnya bahwa berdasarkan kriteria budaya tak benda nomor 4, yang menyatakan bahwa perlu adanya keterlibatan dengan individu, masyarakat, komunitas, dan pemerintah dalam langkah dan strategi dalam memperoleh pengakuan UNESCO. Kelayakan nominasi diakui sebagai sebuah warisan budaya tergantung dari sebagian besar komitmen kelompok, komunitas dan masyarakat. 
Pada penelitian ini, penulis menunjukkan bahwa masyarakat dan komunitas Tari Saman memiliki komitmen dan berupaya untuk menjaga kelestarian Tari Saman. Seperti yang disebutkan dalam deklarasi penggemar budaya Tari Saman:

"Kami, para pelatih, pemain dan penggemar dari warisan budaya Tari Saman, negara kami menghormati dan menghargai tertinggi untuk para pendahulu kita yang telah menciptakan dan mengembangkan gerakan, ayat dinyanyikan, dan motif kostum Tari Saman, bersama dengan nilai-nilai budaya yang terkait dengan mereka, dan melewati mereka ke diri kita sebagai warisan budaya. Kami dengan ini menyatakan tekad kita untuk menghormati satu sama lain dan bekerja sama untuk menjaga dan mengembangkan budaya Tari Saman sebagai salah satu elemen dari warisan budaya bangsa Indonesia." (UNESCO, 2011: 14)

Melalui pernyataan tersebut, terlihat bahwa terdapat adanya kemauan atau komitmen dari masyarakat Gayo Lues dan Komunitas Tari Saman untuk berusaha melestarikan Tari Saman melalui pendaftaran dan pengakuan UNESCO atas Tari Saman Gayo sebagai warisan budaya dunia tak benda. Selain itu, adanya kerja sama antara Pemerintah Daerah dan Pemerintah Pusat dalam pengajuan Tari Saman Gayo ke UNESCO dalam menjaga keberadaan budaya Indonesia untuk mendukung eksistensi identitas bangsa Indonesia melalui manifestasi nilainilai budaya yang memiliki filosofi tinggi.

\section{PRAKTEK DAN HAMBATAN DIPLOMASI TARI SAMAN GAYO}

Dalam proses menjadikan Tari Saman Gayo sebagai nominasi warisan budaya tak benda, hingga pada akhirnya memperoleh pengakuan sebagai warisan budaya tak benda oleh UNESCO, ada langkah-langkah diplomasi untuk mencapainya. Namun terdapat juga hambatan-hambatan dalam proses menjadikan Tari Saman sebagai warisan budaya tak benda. Pada bagian ini penulis akan menganalisa praktek dan hambatan proses diplomasi Tari Saman Gayo.

Awal mula inisiatif untuk mendaftarkan Tari Saman sebagai warisan budaya tak benda datang dari komunitas Tari Saman dengan beberapa alasan yang sudah dijelaskan sebelumnya. Komunitas Tari Saman meminta dukungan dan bekerja sama dengan pemerintah Gayo Lues agar bisa mendapatkan bantuan serta dukungan dari pemerintahan Indonesia untuk menjadikan Tari Saman sebagai warisan budaya dunia asli Indonesia.

Perwujudan misi untuk menjadikan Tari Saman sebagai warisan budaya dunia asli Indonesia sudah dilakukan oleh komunitas Tari Saman dengan menampilkan Tari Saman di luar negeri sebelum adanya pengakuan dari UNESCO. Tari Saman dipilih sebagai nominasi daftar warisan tak benda karena mengingat tarian asal Aceh itu memang dinilai membutuhkan perlindungan dan paling siap dengan berkas-berkas dan file nominasi. Karena untuk menghindari kepunahan dan klaim dari bangsa lain, maka perlu adanya pengakuan, pelestarian, pengembangan serta promosi. Dukungan yang diberikan pemerintah adalah dengan memberikan bantuan sebesar sepuluh juta dolar Amerika guna menjaga, mendukung kegiatan identifikasi budaya, melestarikan, dan mengembangkan budaya Tari Saman.

Untuk mendaftarkan Tari Saman ke UNESCO sebagai nominasi warisan budaya tak benda harus memenuhi formulir serta kriteria-kriteria yang harus telah ditentukan oleh UNESCO. Untuk memenuhi hal-hal tersebut, Kementrian Budaya dan Pariwisata membentuk tim dan melakukan observasi lapangan di daerah Gayo Lues serta daerah Provinsi Aceh sekitarnya pada bulan Februari 2009 (UNESCO, 2011). Kesulitan yang dialami adalah daerah Gayo Lues berada di daerah pegunungan dan daerah sangat sulit untuk dijangkau. Transportasi dan medan untuk menjangkau ke daerah Gayo Lues cukup sulit, sehingga ini menjadi salah satu kendala bagi para tim observasi.

Sedangkan adanya batas waktu untu menyerahkan file formulir untuk diserahkan kepada sekretariat, ditambah file formulir juga harus disertakan oleh video dan foto. Sehingga harus ada tambahan waktu untuk membuat video Tari Saman dalam waktu 10 menit. Dalam video yang berdurasi 10 menit, tim beserta 
masyarakat Gayo Lues juga harus bisa menjelaskan semuanya. Hambatan selanjutnya adalah karena kantor budaya yang menyimpan file-file Tari Saman sudah tidak ditemukan karena adanya bencana tsunami pada Desember tahun 2004.

Setelah melakukan observasi lapangan, Pemerintah Daerah melalui tim dari Kementrian Budaya dan Pariwisata harus membuat file nominasi ke dalam bahasa inggris. Hal yang paling menyulitkan untuk membuat file formulir ini adalah Tari Saman harus dijelaskan secara jelas, namun singkat. Sebelum file formulir ini diberikan kepada Duta Besar Republik Indonesia di Paris dan akan diserahkan kepada sekretariat UNESCO, tim dari Kementrian Budaya dan Pariwisata mengadakan sidang verifikasi bersama masyarakat Gayo Lues, para komunitas Tari Saman, serta perwakilan masyarakat dari beberapa daerah Aceh.

Hal yang menjadi kendala dalam memperoleh Tari Saman sebagai warisan budaya tak benda adalah masalah waktu, adanya batasan waktu untuk pengumpulan file formulir. Sementara itu dalam observasi lapangan cukup memakan waktu yang lama, ditambah dengan pembuatan video, dan membuat file formulir dengan bahasa inggris. Kementrian Budaya dan Pariwisata Republik Indonesia memang sangat hati-hati dalam pengisian file formulir ini karena harus bisa menjelaskan alasan-alasan mengapa Tari Saman ini ingin didaftarkan menjadi warisan budaya tak benda, nilai-nilai filosofis Tari Saman, dan kebutuhankebutuhan yang diperlukan untuk mengembangkan Tari Saman.

Tulisan ini hanya ingin menegaskan bahwa diplomasi budaya Indonesia melalui Tari Saman Gayo adalah salah satu bentuk soft power yang digunakan pemerintah Indonesia untuk bisa mengukuhkan identitas nasional bangsa. Hasil penjelasan mengenai praktek dan hambatan dalam proses diplomasi Indonesia dalam tulisan ini bisa saja mengalami perbedaan jika ditulis oleh peneliti lain yang melihat dari sudut pandang berbeda.

\section{KESIMPULAN}

Diplomasi yang dilakukan oleh Indonesia untuk mendapatkan pengakuan Tari Saman Gayo dari UNESCO merupakan suatu cara untuk dapat melindungi eksistensi Tari Saman Gayo dari kepunahan serta menjadi semangat dalam menumbuhkan rasa cinta tanah air sekaligus sebagai pengukuhan bagi identitas bangsa Indonesia yang kaya akan budaya agar mampu menjaga hubungan baik dengan negara lain dan menghindari klaim dari negara tetangga.

Mendapatkan pengakuan akan Tari Saman Gayo sebagai warisan budaya tak benda dari UNESCO untuk mengukuhkan identitas nasional bangsa merupakan bentuk soft power Republik Indonesia dalam mendekati bangsa lain, karena pentingnya menjaga dan melindungi budaya-budaya Indonesia yang memiliki banyak sekali keragaman budaya. Dengan memanfaatkan dimensi budaya, Indonesia melakukan diplomasi untuk menunjukkan soft power sekaligus sebagai satu proses dalam menunjukkan identitas nasional bangsa.

\section{BIBLIOGRAFI}

Bambang Wibawarta. 2012. Transformasi Budaya Membangun Manusia Indonesia Berkesadaran IImu Pengetahuan, Bandung: ITB. Busrizalti. 2013. Negara Kesatuan, HAM \& Demokrasi serta Ketahanan Nasional, Yogyakarta: Total Media.

Nye, Joseph. 2004. Soft Power Means to Success in World Politics, New York: Public Affairs.

Perwita, Agung. 2011. Pengantar Ilmu Hubungan Internasional, Bandung: Rosdakarya.

Rudy, May. 2003. Hubungan Internasional Kontemporer dan Masalahmasalah Global, Bandung: Refika Aditama.

Srijanti, et al. 2008. Etika Berwarga Negara Jilid 2, Jakarta: Salemba Empat

Hendrastomo, Grendi. 2007. Nasionalisme VS Globalisasi, Hilangnya Semangat Kebangsaan. Jurnal Dimensia, Vol. 1 No.1

Manuaba, Putera. 1999. Budaya Daerah dan Jati Diri Bangsa: Pemberdayaan Cerita Rakyat dalam Memasuki Otonomi Daerah dan Globalisasi, Masyarakat, Kebudayaan dan Politik, Th XII, No. 4

Adi, Putra Riski. 2011. Diplomasi Pemerintah Indonesia dalam memperoleh pengakuan Batik dari Unesco, Universitas Muhammadiyah Malang.

Ayu, Rizka. 2012. Soft Diplomacy Korea Selatan, Universitas Hasanuddin.

Declaration of Saman Culture dalam UNESCO. Convention: Saman Dance (Indonesia) Urgent Safeguarding List-2011.

Ringkasan Eksekutif Laporan Dunia UNESCO. 2009. Berinvestasi dalam 


\section{JURNAL HUBUNGAN INTERNASIONAL}

VOL. 4 EDISI 1 / APRIL 2015

Keanekaragaman Budaya dan Dialog Antar budaya.

UNESCO. Convention: Saman Dance (Indonesia) Urgent Safeguarding List-2011

Antaranews. 2007. Malaysia klaim 7 budaya Indonesia

(antaranews.com, diakses 02 Desember 2013)

UNESCO. Substance Programming Report CAP Thematic Outline:

Protecting, conserving and safeguarding cultural heritage (http:// unesco.org, diakses 10 Februari 2013)

BBC Indonesia. 2011. Unesco Tetapkan Tari Saman sebagai Budaya

Dunia, (www.bbc.co.uk, diakses 10 Februari 2014) 